\title{
Comportamiento homosexual en rumiantes machos. Revisión
}

\section{Homosexual behavior in male ruminants. Review}

\author{
Aline Freitas-de-Meloa, Lorena Lacuestab, Rodolfo Ungerfeldb
}

\begin{abstract}
RESUMEN
En varias especies de rumiantes, tanto domésticos como silvestres, se ha reportado la existencia del comportamiento homosexual entre los machos. El objetivo de esta revisión fue sintetizar la información disponible sobre las diferencias neuroendocrinas entre individuos homo y heterosexuales, y la relación entre la presencia del comportamiento homosexual y la concentración de esteroides sexuales. A su vez, se presenta información que vincula el comportamiento homosexual con la dominancia social, la edad, el ambiente social durante el desarrollo, y los disturbios ambientales. También se analiza como varía el comportamiento homosexual de acuerdo a la estacionalidad reproductiva. Además, se incluye información original sobre la estacionalidad del comportamiento homosexual en carneros domésticos, y de machos de cabra montesa, y su vínculo con la secreción de testosterona. Otro aspecto discutido es el "síndrome de buller" en novillos, individuos que son sistemáticamente montados por otros, y algunos de los factores asociados con la ocurrencia de este síndrome. En síntesis, el comportamiento homosexual en los rumiantes machos tiene un origen etiológico diverso, estando algunos aspectos aún poco estudiados, por lo que toda interpretación debe ser considerada con cautela, siendo por lo tanto un campo de estudio a profundizar.
\end{abstract}

PALABRAS CLAVE: Comportamiento sexual, Núcleo sexual dimórfico, Orientación sexual, Síndrome de buller, Testosterona, Ungulados.

\begin{abstract}
In several male ruminants, including both, domestic and wild species, it has been reported the presence of homosexual behaviour between males. The aim of this review was to summarize the information about neuroendocrinological differences between homo and heterosexual individuals, and the relationship between homosexual behaviour and sexual steroid concentration. Moreover, we present information that link homosexual behavior with social dominance, age, social environment during the developmental period, and environment disturbances. Therefore, we include information about other physiologic aspects, such as reproductive seasonality, including unpublished information about seasonal changes in domestic rams and captive male I berian ibex, and the relationship between seasonal changes in testosterone and behaviour. Other topic discussed is the "buller syndrome", which is commonly observed in steers, in which is observed that some males are repeatedly mounted by others males. In brief, homosexual behaviour in male ruminants is multietiologic, and some aspects are understudied, so the interpretation may be cautiously considered before deep studies are developed.
\end{abstract}

KEY WORDS: Sexual behavior, Sexually dimorphic area, Sexual orientation, Buller syndrome, Testosterone, Ungulates.

\section{INTRODUCCIÓN}

El comportamiento homosexual puede ser definido como una interacción sexual entre dos o más individuos del mismo sexo, la que puede ser casual o permanente(1). Se ha reportado la

\section{INTRODUCTION}

Homosexual behavior may be defined as casual or permanent sexual interaction between two or more individuals from the same gender(1). Homosexual behavior between males has been

Recibido el 24 de septiembre de 2012. Aceptado el 2 de abril de 2013.

a Departamento de Biología Molecular y Celular, Universidad de la República, Lasplaces 1550, Montevideo (11600), Uruguay , tel. (598) 26221195. alinefreitasdemelo@hotmail.com. Correspondencia al primer autor.

b Departamento de Fisiología, Facultad de Veterinaria, Universidad de la República. Montevideo, Uruguay. 
existencia del comportamiento homosexual entre machos de varias especies de rumiantes, incluyendo a los ovinos(2), caprinos(3), bovinos $(4,5)$, bisontes(6), jirafa, antílope, buey almizclero(7) y varias especies de cérvidos $(7,8)$. De manera general, la monta intrasexual (monta entre individuos del mismo sexo) ocurre en ambos sexos, entre animales de todas las edades, tanto en vida libre como en cautiverio(7). Es frecuentemente observada entre los machos(9), estando en las hembras de rumiantes asociada al celo(10). Además, es más frecuente en animales juveniles que en adultos, y en individuos domésticos y en cautiverio que en animales libres(11). La homosexualidad en rumiantes machos puede estar asociada a muchos factores, tales como la dominancia social(12), la edad(13), o el ambiente social durante el desarrollo(14), pudiendo también ser inducida por disturbios ambientales(11).

En algunos casos, el comportamiento homosexual puede implicar un problema importante desde el punto de vista productivo, como sucede con el "síndrome de buller" en los novillos, donde algunos individuos son sistemáticamente montados por otros(12,15). En condiciones de feed-lot, algunos autores estudiaron la frecuencia de este comportamiento entre más de 5 millones(16) de animales y cerca de 80.000 en otro trabajo(17), y coinciden en que algo más del $2 \%$ de los animales presentaron el "síndrome de buller". Se reportó que la mortalidad puede llegar al $1 \%(16)$, y que estos animales se agotan al ser montados en forma reiterada, pierden pelo y presentan inflamaciones y traumas en la grupa y la cola, pudiendo en casos extremos sufrir fracturas de huesos(18). Adicionalmente, se planteó la hipótesis de que el "síndrome de buller" en bovinos se vincula al establecimiento de la jerarquía social entre machos(12).

Esta revisión presenta una síntesis de trabajos en los que se estudiaron los principales factores que influencian o determinan la homosexualidad en rumiantes machos, además de incluir reported in several ruminant species, including sheep(4), goats(5), bison(6), giraffes, antelopes, musk ox $(7)$ and some deer species $(7,8)$. In general, intrasexual mount (between members of the same sex) is common in both sexes irrespective of age of the animals, and either in animals that live in freedom or in captivity(7). It is frequently observed in males $(9)$, and in estrual ruminant females(10). Besides, homosexual behavior is more frequent in young individuals than in adults and in domesticated animals living in captivity than in those free in the wild(11). Homosexuality in male ruminants can be associated to several factors, such as social dominance(12), age(13), the social environment during growth(14), but it can also be induced by environmental disruptions(11).

In some cases, homosexual behavior constitutes an important productive problem, as happens with the "Buller syndrome" (riding behavior) in steers $(12,15)$. Some authors studied the frequency of this behavior, in which some animals are systematically mounted by others in feed-lot conditions, in more than 5 million individuals(16) in one study and in 80 thousand in another(17). In both of them, more than $2 \%$ of the animals presented the Buller syndrome. Mortality in these cases can reach almost $1 \%(16)$. Animals that are repeatedly mounted becomes exhausted, loose hair, resulting inswelling and trauma on the rump and tail head, and even bone fractures(18). It has been proposed that the Buller syndrome is related to the establishment of dominance relationships(12).

The present review summarizes the information presented in several studies on factors that can influence or determine homosexuality in male ruminants, including some unpublished information.

\section{Evolutionary perspective}

Homosexuality is considered as an evolutionary paradox, as sexual behaviors are originally developed in a reproductive context(1). As traits that overcome selection pressure present an 
información original en algunos de los puntos planteados.

\section{Perspectiva evolutiva}

La homosexualidad es considerada una paradoja evolutiva, ya que los comportamientos sexuales son originalmente desarrollados en un contexto reproductivo(1). Partiendo de que las características que resisten a la presión de selección presentan una función adaptativa, los evolucionistas buscan explicaciones para el comportamiento homosexual. Algunos autores consideran que el comportamiento homosexual no es producto directo de la selección natural, si no que estaría relacionada genéticamente a otra(s) característica(s) resistentes a la presión de selección(19). Otros autores proponen que el comportamiento homosexual cumple un rol importante en los vínculos sociales, pudiendo ser una forma de comunicar la dominancia frente a otros individuos del grupo (12,15). De acuerdo a una visión bio-socio-antropológica, la misma serviría para promover los vínculos sociales entre los individuos(19). Además, considerando que la homosexualidad es más frecuente cuando hay altas densidades poblacionales(8), también podría servir para disminuir o mantener el tamaño de las poblaciones con altas densidades, reduciendo la inversión en la reproducción para garantizar la disponibilidad de alimento(19). Por tanto, el comportamiento homosexual podría no desaparecer a pesar de disminuir la probabilidad de dejar descendencia, ya que podría tener funciones sociales que contribuyen al mantenimiento o la adaptación de las especies.

Bases neuroendocrinas de la homosexualidad

Desde hace mucho tiempo se ha intentado determinar si existe una base neural que diferencia a los individuos que despliegan más frecuentemente comportamientos homosexuales(20). Si bien es difícil atribuir el comportamiento en forma lineal a diferencias neurales, las mismas han sido consideradas una de las posibles causas(2) de un fenómeno que probablemente sea de etiología múltiple. En el caso de los rumiantes, adaptive function, evolutionists tried to explain homosexual behavior. Some authors explain that homosexual behavior is not a direct consequence of natural selection, and it should be genetically related to other traits that overcome selection pressure $(19)$. Other authors suggest that homosexual behavior plays an important role in social bonds, being a signal of dominance directed to other members of the group $(12,15)$. In accordance with a bio-socialanthropological perspective, homosexual behavior would be useful for promoting social bonds between individuals(19). Taking into account that homosexuality is more frequent in high density populations(8) it could be helpful for diminishing or maintaining the size of these populations, thus reducing the investment in reproduction needed according to food availability(19). Therefore, homosexual behavior would not disappear even if the probability of having offspring drops, as it would also have social functions which contribute to species survival and adaptation.

Neuroendocrine basis of homosexual behavior

For many years researchers searched for a neural basis differing in homosexual and heterosexual individuals(20). Even if it is difficult to attribute this behavior directly to neural differences, it has been considered as a possible cause(2) of an event which is most probably multietiological. In the specific case of ruminants, the model most widely studied was the ram, specifically rams that prefer mounting rams instead of estrual females, a trait that in some breeds can reach up to $8 \%$ of the population. These rams not only mount, but also direct all courtship activities (anal-genital smelling, kicks and lateral approach) to other rams, while their sexual activity toward females is extremely $\operatorname{low}^{(21)}$.

The central medial preoptic area (APOM), located in the anterior hypothalamus, is related to mating behavior in vertebrate males(22). Thus, this structure is of great importance for studying anatomic differences in accordance with 
el modelo de estudio han sido carneros que tienen preferencia sexual por otros carneros frente a ovejas en celo, lo que en algunas razas constituye hasta el $8 \%$ de la población(1). Estos carneros no solo montan, sino que dirigen todas las actividades de cortejo (olfateos anogenitales, acercamientos laterales y pataleos) hacia otros carneros, al tiempo que su actividad sexual frente a hembras es muy baja(21).

\section{Diferencias en el sistema nervioso central}

El área preóptica medial (APOM), localizada rostralmente en el hipotálamo, está relacionada principalmente al comportamiento de cópula en los vertebrados machos(22). Por eso, esta estructura es de gran interés para el estudio de las diferencias anatómicas de acuerdo a la orientación sexual. En ratas se descubrió un núcleo en el APOM, llamado núcleo sexual dimórfico (NSD), que difiere en tamaño entre machos y hembras(23). El tamaño del NSD también difiere en los ovinos de acuerdo al sexo, y en los carneros de acuerdo a la orientación sexual. En este sentido, el tamaño del NSD es mayor en los carneros heterosexuales que en las ovejas, o que en carneros que prefieren montar a otros carneros en lugar de ovejas(24). Si bien esto no permite determinar relaciones de causa-efecto entre el tamaño del NSD y la orientación sexual, al menos permite afirmar que existen diferencias anatómicas que podrían explicar parcialmente las preferencias sexuales de estos carneros. Más aún, las diferencias de tamaño no se vinculan con diferencias en las concentraciones séricas de testosterona, manteniéndose las mismas diferencias aún en animales adultos gonadectomizados y tratados con testosterona(25). También se ha reportado que la exposición a testosterona en el periodo prenatal aumenta el tamaño del NSD de las corderas(26). Además, las ovejas tratadas con andrógenos durante el periodo prenatal presentan menor comportamiento de receptividad al macho(27). Por lo tanto, las variaciones en la concentración de testosterona en el periodo prenatal podrían afectar el sexual preference. In rats, there is a nucleus in APOM, called the sexually dimorphic nucleus (NSD), which is different in size in males and females(23). This is true also in ovines, but also in rams with different sexual preference: it is bigger in heterosexual rams than in either ewes or homosexual rams(24). Even though this does not definitely establish a cause-effect relationship between NSD size and sexual preference, at least allows explaining partially the sexual preference of these rams. Even more, differences in size are not linked to testosterone serum concentrations, as the same differences are observed even in castrated adult males treated with testosterone(25). Other authors(26) reported that female lambs prenatally treated with testosterone had NSD sizes. Even more, ewes treated with androgens during their prenatal stage are less receptive towards males(27). Therefore, changes in testosterone concentration during the prenatal period could affect NSD development in ovines, linking it to differences in NSD size in adults.

During the late gestation of male lambs, there is a high RNAm expression for aromatase in both, hypothalamus and amygdale, expressed during the critical brain sexual differentiation period(28). Aromatase is the enzyme that converts androgens into estrogens(29). This is important because these estrogens generated at the local level from circulating androgens are the responsible hormones stimulating sexual behavior in adult males(30). At the same time, expression of this enzyme in lamb late gestation suggests that aromatization is necessary for brain masculinization, as happens in rats, mice and pigs(31). However, administration of an aromatase inhibitor in lamb fetuses did not change either their sexual preference(32) or NSD size(33) when reaching adulthood, being the only difference a lower mounting activity when rams reached 18 mo of age. This difference could be due to sensitivity to estrogens, because the amount of estrogen receptors in the amygdala is lower in homosexual than heterosexual rams(34). In later studies it was reported that there is no brain masculinization 
desarrollo del NSD en ovinos, vinculándose con las diferencias en el tamaño del NSD en los individuos adultos.

Durante la gestación tardía de corderos machos, en el periodo crítico de diferenciación sexual del cerebro, hay una alta expresión de RNAm para aromatasa en el hipotálamo y en la amígdala(28). La aromatasa es la enzima encargada de la conversión de andrógenos a estrógenos(29). Esto es importante porque estos estrógenos generados a nivel local a partir de los andrógenos circulantes son los que estimulan el comportamiento sexual en los machos adultos(30). A su vez, la expresión de esta enzima durante la gestación avanzada en corderos sugeriría que la aromatización es necesaria para la masculinización del cerebro, tal como ocurre en ratas, ratones y cerdos(31). Sin embargo, la administración de un inhibidor de la aromatasa en fetos de corderos no alteró la preferencia sexual(32), ni el tamaño del NSD(33) de esos animales cuando alcanzaron la vida adulta. La única diferencia observada en estos carneros fue una reducción en el comportamiento de monta a los 18 meses(32). La diferencia estaría probablemente dada por la sensibilidad a los estrógenos, dado que la cantidad de receptores de estrógenos en la amígdala es menor en carneros homosexuales que en carneros heterosexuales(34). En trabajos posteriores, se observó que al aumentar la dosis del inhibidor y el tiempo de tratamiento, tampoco se observó una pérdida de la masculinización cerebral(20). Aunque no existan trabajos en otros rumiantes, en carneros la aromatización parece no ser necesaria para la masculinización del cerebro.

Dado que en ratas se ha observado un vínculo entre la cantidad del neurotransmisor cerebral monoamino-oxidasa tipo A (MAO-A) y el comportamiento de dominancia(35), un estudio(36) comparó la cantidad de MAO-A en la corteza frontal de novillos que aceptan la monta de otros machos y aquéllos que no, encontrando que está disminuida un $75 \%$ en aquellos machos que aceptan ser montados por loss when the dose of the inhibitor or the length of the treatment were increased(20). Although there are no studies in other ruminants, at least in rams seems that aromatization is not necessary for brain masculinization.

As the amount of monoamino oxidase type $A$ (MAO-A) brain neurotransmitter and dominance behavior are related in rats(35), a study compared the MAO-A amount in the front cortex of steers that accept being mounted by other males and those who do not. It was observed that MAO-A was reduced $75 \%$ in steers that accepted being mounted. This suggests that there are differences at the SNC level in "Buller syndrome" steers, and that these differences could be linked to the social position of these animals.

The response of the hypothalamus-hypophysis axis to estradiol has been also studied. When high doses of estradiol are administered to ewes, the hypophysis responds secreting $\operatorname{LH}(37,38)$. However, estradiol do not produce a LH response in heterosexual male humans, but does it in homosexuals $(39,40)$. Therefore, this response could be an indicator of an incomplete brain masculinization. However, no rams secreted LH in response to estrogen treatments, regardless of their sexual preference $(34,41)$. Therefore in these studies it is suggested that brain masculinization in ruminants takes place in the prenatal period irrespective of sexual orientation, thus rendering impossible a $\mathrm{LH}$ response to estradiol treatments(2).

\section{Endocrine differences}

Testosterone is the main hormone related to male sexual behavior(22), which can influence homosexual behavior too. For example, entire males mount more than those castrated $(4,42)$, and bulls reduce the frequency of their mounting behavior after blocking their testosterone (Andreae et al, quoted in Bartoš L, Holeèková J. Exciting ungulates: male-male mounting in fallow, white-tailed and red deer(19)).

It is interesting to notice that serum testosterone concentration in the spermatic vein is higher in 
otros machos. Esto permitiría sugerir que hay diferencias a nivel del SNC en los novillos con "síndrome de buller", y que estas diferencias podrían estar vinculadas a la posición social de los animales.

También se ha estudiado la respuesta del eje hipotálamo-hipofisario a la administración de estradiol. Cuando se administran dosis altas de estradiol a las ovejas la hipófisis responde secretando $\mathrm{LH}(37,38)$. En hombres heterosexuales el tratamiento con estradiol no genera una respuesta de LH, pero en hombres homosexuales si $(39,40)$. Por tanto, esta respuesta sería un indicador de una masculinización incompleta del cerebro. Sin embargo, ningún carnero secretó LH como respuesta a la administración de estrógenos, independientemente de que fueran homo o heterosexuales $(34,41)$. Por tanto, en estos trabajos se sugiere que el cerebro de los rumiantes, se masculiniza durante el periodo prenatal independientemente de la orientación sexual, imposibilitando la respuesta de $\mathrm{LH}$ al tratamiento con estradiol(2).

\section{Diferencias endocrinas}

La testosterona es la principal hormona relacionada a los comportamientos sexuales masculinos(22), pudiendo influir también sobre el comportamiento homosexual. Por ejemplo, los machos intactos montan más a otros machos que a los castrados $(4,42)$, y los toros reducen la frecuencia de sus comportamientos de monta si son tratados bloqueando la testosterona (Andreae et al, 1981 citado por(8)).

Es interesante que la concentración sérica de testosterona de la vena espermática de los carneros que prefieren montar a otros carneros que a ovejas, es menor que la de los carneros que tienen preferencia por hembras $(43,44)$. Ello permitiría suponer que hay una relación entre la presencia de comportamiento homosexual y la concentración de testosterona. Sin embargo, en ciervo dama (Dama dama) no se encontró relación entre la concentración de testosterona y la frecuencia de montas entre machos(45), rams that prefer mounting females than in those preferring males $(43,44)$. This would to speculate with a relationship between testosterone concentration and homosexual behavior. However in fallow deer (Dama dama) there is no relationship between testosterone concentration and inter-male mounting frequency(45), although an increase was observed during the horn growth stage, when testosterone concentration begins to increase(46). In rams, Lacuesta and Ungerfeld (unpublished) did not find any relationship between inter-male mounting frequency and testosterone concentration, even during or outside the breeding season.

On the other hand, the buller syndrome seems to be associated to steroid hormone concentration. Apparently, estrogens increase the frequency of this syndrome, and testosterone decreases it(15). Anyway, data available in ruminants which link sexual steroid concentrations to homosexual interactions is scarce.

\section{Sensorial differences}

It has been suggested that differences between homosexual and heterosexual rams could be due to the olfactory system, which in turn could affect NSD organization, thus altering sexual preferences(1). Even though more studies on this aspect are necessary for determining the existence of sensorial differences between homosexual and heterosexual males, some studies suggest their presence. The amount of estrogen receptors found in amygdala in homosexual rams is lower than in heterosexual rams, and practically the same as in females(34). These authors speculated that the amygdala plays an important role in sexual orientation, linking sensorial perception with performance of sexual behavior. In fact, in humans, functional connectivity between the left and right amygdala changes in accordance with sexual orientation(46).

It is known that exposing heterosexual rams to sexually receptive females causes an increase 
aunque hay un aumento en la cantidad de montas entre machos durante el periodo de crecimiento de las astas, etapa que inicia el aumento de la concentración de testosterona(45). En carneros, Lacuesta y Ungerfeld (datos no publicados), tampoco encontraron una relación entre la frecuencia de montas entre machos y la concentración de testosterona, durante o fuera de la estación reproductiva.

Por otro lado, el síndrome de buller parece estar asociado con la concentración de hormonas esteroideas. Se observó, que mientras los estrógenos aparentemente elevan la frecuencia de buller, la testosterona disminuye su ocurrencia(15). De todas formas, es muy limitada aún la información disponible en rumiantes que vincule la concentración de esteroides sexuales con las interacciones homosexuales.

\section{Diferencias sensoriales}

Se propuso que la diferencia entre los carneros homosexuales y heterosexuales podría estar en el sistema olfatorio, el que a su vez afectaría la organización del NSD, y por tanto alteraría la preferencia sexual(1). Si bien es necesario realizar más estudios para determinar si existen diferencias sensoriales entre rumiantes machos homo y heterosexuales, hay algunos trabajos que sugieren la existencia de las mismas. Se reportó que la cantidad de receptores de estrógenos presentes en la amígdala es similar en carneros homosexuales y hembras, al tiempo que es mayor en machos heterosexuales(34). Estos autores especularon con la existencia de diferencias en la percepción sensorial entre carneros homo y heterosexuales, ya que la amígdala tiene un papel importante en la orientación sexual, vinculando la percepción sensorial con la ejecución de los comportamientos sexuales. De hecho, en humanos se ha reportado que las conexiones funcionales entre la amígdala derecha e izquierda varían de acuerdo a la orientación sexual(46).

Es conocido que la exposición de carneros heterosexuales a una hembra en celo provoca in both $\mathrm{LH}$ and testosterone secretion $(47,48)$. However, male oriented rams do not secrete $\mathrm{LH}$ in presence of sexually receptive females(48). At this point it is deemed important to clarify that these same rams are able to secrete $\mathrm{LH}$ in response to treatment with $\mathrm{GnRH}$, so the factor which limits the endocrine response to receptive female it is not the adeno-hypophysis functionality. Therefore, heterosexual and homosexual ruminant males may have differences on how they perceive those stimuli. These differences might be found in either the primary or secondary olfactory system or in neuronal processing(48), although other signaling processes should not be discarded.

\section{ENVIRONMENT}

Social dominance and age

Some authors propose that inter-male mounting in ruminants is linked to social dominance [Gazelle (Gazella granti) Walther quoted by(8); White tailed deer (Odocoileus virginianus) Rue, quoted by $(8)$; steers, quoted by $(12,49)]$. In Soay lambs living in freedom, inter-male mounts are more frequent than male-female mounts, a fact that led $\mathrm{Grubb}(50)$ to propose that this behavior is an indication of social dominance. Differences in MAO-A amounts found in the brain cortex of steers who accept and not accept being mounted by other males(36) are similar to those reported before in dominant or subordinate rats(35). This might indicate an association between males who accept being mounted and their social rank. In this sense, some authors(12) consider that the establishment of the social hierarchy provokes the buller syndrome. In bison, if age is not considered, subordinates start and receive more homosexual interactions than dominant individuals. However, when age is considered, those disappeared(51). This led those authors to propose that age influences more than dominance on the display of homosexual behavior. Even though this explanation may be valid in certain circumstances; other authors $(13,52)$ proposed that homosexual behavior in lambs is more related to their growth stage than to their social 
un aumento en la secreción de LH y testosterona $(47,48)$. Sin embargo, los carneros que prefieren montar otros machos no responden a la presencia de hembras con secreción de $\mathrm{LH}^{(48)}$. Es importante aclarar que estos mismos carneros son capaces de secretar LH como respuesta a la administración de GnRH, por lo que no es la funcionalidad de la adenohipófisis lo que limita la respuesta endocrina a la presencia de hembras. Por tanto, se plantea que podrían existir diferencias sensoriales entre rumiantes machos heterosexuales y homosexuales debidas a peculiaridades en la captación de los estímulos. Estas diferencias podrían ser en el sistema olfatorio primario y secundario, o en el procesamiento neuronal(48), aunque no es posible descartar otras vías de señalización.

\section{AMBIENTE}

Dominancia social y edad

Algunos autores propusieron que la monta entre rumiantes machos se vincula con la dominancia social [gazela (Gazella granti): Walther (1965) citado por(8); ciervo de cola blanca (Odocoileus virginianus): Rue (1989) citado por(8); novillo:(12,49))]. En corderos Soay en vida libre, la monta entre machos es incluso más frecuente que entre machos y hembras, lo que llevó a Grubb(50) a plantear que este comportamiento es un signo de establecimiento de dominancia. Las diferencias en la cantidad de MAO-A encontradas en la corteza de novillos que aceptan o no la monta de otros machos(36), son similares a las reportadas anteriormente en ratas dominantes o subordinadas(35). Esto podría indicar una relación entre los machos que aceptan montas y su posición social. En este sentido, algunos autores(12) especulan que el establecimiento de la jerarquía social es la causa principal del síndrome de buller. En bisontes, sin considerar el factor edad, los individuos subordinados inician y reciben más interacciones homosexuales que los dominantes, pero al considerar la edad se pierden estas diferencias de acuerdo a la dominancia(51). Estos autores sugieren que esto indica que la edad rank. These authors did not find significant relationships between dominance and male-male mounting. Even more, in those studies it was found that development of homosexual behavior in lambs is related to the development of heterosexual behavior. In this sense, it was proposed that male-male mounting in rams is part of normal sexual behavior(44).

Frequency of homosexual behavior is very high in young males, which could be due to stimulation generated by hormonal changes, but also a learning stage(8). A peak in homosexual mounts in domestic lambs is recorded when they are 5 to 6 mo old(13). In white tailed deer and bison, inter-male mounting frequency is also related to age, being more frequent in young than adult animals(51). In summary, while some authors suggest that homosexual behavior is linked to social dominance, this behavior seems to be more linked to age (more frequent in young individuals), as no studies on homosexual behavior in ruminants obtained a clear relationship between social dominance and presence of homosexual behavior.

Social environment during growth

Homosexual behavior in domestic male ruminants is more frequent when they are reared in single male groups(11). In this sense, it was reported that rams isolated for long periods from females display increase the frequency of homosexual behavior(14). On the other hand, other authors proposed that the social environment during rearing influences sexual performance but not sexual preferences(53). Regarding this, exposing yearling rams early to females, increases the probability of being sexually active, but does not prevent homosexuality(54,55).

Some authors reported that bucks reared isolated from females displayed more sexual activity toward other males than those reared with females, suggesting that lack of contact with females facilitates recognizing other males as sexual partners(56). However, there were no 
tiene mayor importancia en el despliegue de comportamiento homosexual que la dominancia. Además, aunque esta explicación pueda ser válida en ciertas condiciones, algunos autores $(13,52)$ plantearon que los comportamientos homosexuales de los corderos parecen estar más vinculados a su etapa de desarrollo que a relaciones de dominancia. Estos autores no encontraron una relación entre dominancia y montas entre machos. Más aún, en estos trabajos se observó que el desarrollo de los comportamientos homosexuales de los corderos se asocia al desarrollo de los comportamientos heterosexuales. En el mismo sentido, se planteó que en carneros las montas entre machos son parte del comportamiento sexual normal(44).

La frecuencia de comportamientos homosexuales es muy alta entre machos juveniles, lo que podría ocurrir debido al estímulo generado por los cambios hormonales, y por ser una forma de aprendizaje(8). En grupos de corderos domésticos se registró un aumento muy marcado en la frecuencia de de montas entre los 5 y 6 meses de edad(13). En ciervo de cola blanca, la frecuencia de monta entre machos también está relacionada con la edad, siendo máxima en animales juveniles y mínima en adultos(8). También en bisontes los machos juveniles despliegan más frecuentemente el comportamiento homosexual que los adultos(51). En síntesis, si bien algunos autores proponen que el comportamiento homosexual está vinculado a la dominancia, el despliegue de este comportamiento parecería estar más vinculado con la edad (siendo más frecuente en los juveniles), ya que no existen trabajos en rumiantes que hayan encontrado un vínculo entre la dominancia social y la ocurrencia del comportamiento homosexual.

Ambiente social durante el desarrollo

El comportamiento homosexual de los rumiantes machos domésticos es más frecuente cuando estos fueron criados solamente con individuos del mismo sexo(11). En el mismo sentido, se reportó que el comportamiento homosexual de differences in testosterone concentration between both groups. Anyway, when later tested for sexual preference, these bucks did not prefer males over estrous females. In short, males reared without females can influence homosexual activity, but seems no to influence sexual preference.

\section{Environment disruptions}

In general, inter-male mounting frequency increases when animals from different groups are mixed(11). For example, mounting frequency between both bulls and steers increases when new groups are formed(4) or when regrouped in slaughter houses $(49,57)$. In this case, the increase in mounts is significant during the first four hours, particularly between vasectomized males, affecting even meat quality(59). In red deer (Cervus elaphus) inter-male mounts increase in pre-slaughter pens(59). In addition, inter-male mounting increases when males are temporarily confined with other males.

In feed-lot steers, buller syndrome frequency is greater in big groups than in smaller, and in greater density groups(60). Besides, changes in cattle management routines, inadequate feeding and introduction of new animals in a group increase buller syndrome frequency(61).

In Pampas deer (Ozotoceros bezoarticus) no inter-male mounting was seen in two groups of males overseen for more than $200 \mathrm{~h}$ throughout one year (Delbene and Ungerfeld, unpublished). However, the only inter-male mounting observed was when one male was recovering from anesthesia (Fumagalli, personal communication). This animal's condition was most probably what allowed a behavior not usually seen in this specie, and is consistent with an increase in agonist behavior directed to anesthetized animals, as reported in Bighorn rams(62) and Fallow deer (Dama dama)(63). Therefore, considering that environmental disruptions can lead to an increase in inter-male mounts, this can also be a useful tool for studying factors which influence homosexual mating behavior(56). 
los carneros es consecuencia del prologado aislamiento de las hembras y la exclusiva asociación con machos(14). Por el contrario, se planteó que el ambiente social en que se desarrollan los corderos influye sobre el desempeño sexual, pero no sobre la preferencia sexual(53). En este sentido, la exposición temprana de carneros a hembras aumenta las posibilidades de que estos sean sexualmente activos, pero no previene el comportamiento homosexual $(54,55)$.

Algunos autores reportaron que los chivos criados aislados de hembras durante el desarrollo desplegaron más comportamientos sexuales frente a otros chivos que los chivos criados con hembras, planteando que la falta de contacto de esos individuos con hembras facilita que otros machos sean reconocidos como un estímulo sexual(56). A su vez, no se observaron diferencias en las concentraciones de testosterona entre estos grupos de animales. De todas formas, cuando posteriormente fueron sometidos a pruebas de preferencia, estos chivos

Figura 1. Número total de montas (- $\bullet$-) y concentración de testosterona (barras grises) a lo largo de un año en dos grupos de machos (4-5 machos) de cabras montesas (Capra pyrenaica) en cautiverio

Figure 1. Total number of matings (- - -) and testosterone concentration (grey barrs) during one year in two groups of males (4-5 males) of captive Iberian ibex (Capra pyrenaica)

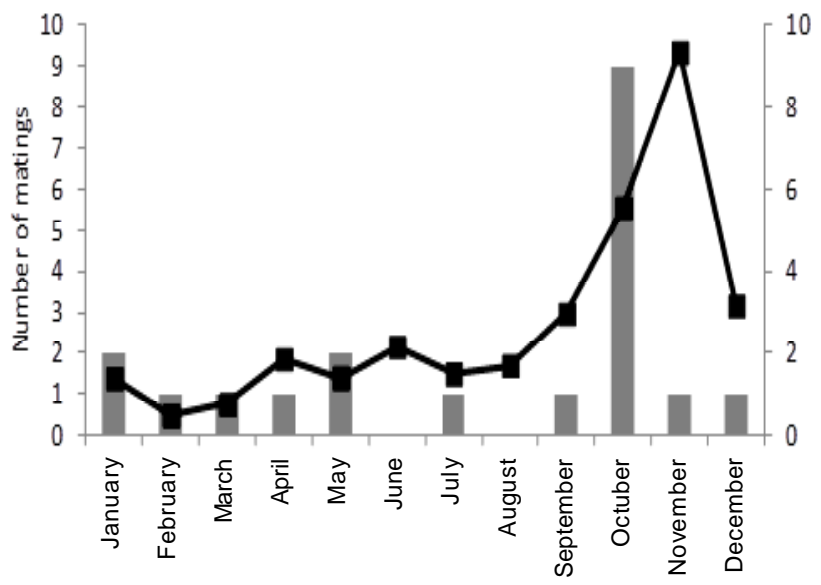

\section{Seasonality}

Several ruminant species show seasonal changes in reproductive activity, which influences the display of sexual behavior throughout the year(64). Therefore, a number of studies focused on seasonal changes in the display of homosexual behavior.

In Fallow deer inter-male mounting frequency is definitely seasonal, being associated to the first three months of antler growth(45). In bison, on the other hand, inter-male mounting increases outside the reproductive season(51), and in White Tailed deer inter-male mounting does not follow a seasonal pattern(8).

In grazing steers a greater frequency of the buller syndrome was observed in fall and summer than in winter and spring in one study $(65)$, and in summer in another(61). Even though its cause was not studied, these authors stated that the buller syndrome is more frequent in the warmer months, coinciding with the period when animals graze of pastures rich in phytoestrogens(15). In agreement, it has been proposed that the buller syndrome is most probably associated to estrogen concentration, which would promote release of sexually attractive pheromones(12).

Weekly records were carried out of Pyrenean I bex (Capra pyrenaica) males in captivity, kept in pens of $250 \mathrm{~m}^{2}$ in groups of 4 and 5 animals each. Animals were fed daily with barley and alfalfa and accustomed to presence of humans. 20 inter-male mounts were recorded throughout the year (Freitas-de-Melo, et al, unpublished). Mounts followed a seasonal pattern, being more frequent at the beginning of the breeding season, when testosterone concentration increases (Figure 1). Other authors observed a similar pattern in Fallow deer, in coincidence with an increase in testosterone concentration(45).

A study was performed recently by the present authors in which different sexual behaviors of Corriedale* Milchschaf rams kept in a $10 * 10 \mathrm{~m}$ pen for one year were weekly recorded. 
no mostraron preferencias por otros chivos frente a hembras en diestro. En síntesis, la cría de machos aislados de hembras puede influir sobre la frecuencia de despliegue del comportamiento homosexual en rumiantes machos, pero parece no influir en la preferencia sexual.

\section{Disturbios ambientales}

En general la frecuencia de montas entre rumiantes machos aumenta con el reagrupamiento de animales(11). Por ejemplo, la frecuencia de montas entre toros y entre novillos aumenta con la formación de nuevos grupos(4), o cuando los mismos son reagrupados en mataderos $(57,49)$. En este último caso, el aumento de montas es muy importante durante las primeras $4 \mathrm{~h}$, particularmente entre machos vasectomizados, pudiendo incluso afectar la calidad de la carne(58). En ciervo rojo (Cervus elaphus) se ha observado que la frecuencia de montas entre machos aumenta en los corrales de espera antes de la faena(59). Además, en ciervo rojo también aumenta la cantidad de montas cuando unos machos son confinados temporalmente con otros machos(8).

En novillos engordados en feed-lot, es mayor la frecuencia del síndrome de buller en grupos grandes que en pequeños, y en altas densidades que en bajas(60). Además, se propuso que los cambios y aumento en la rutina de manejo, la alimentación inadecuada y la inclusión de animales nuevos en el grupo producen un aumento de la frecuencia del síndrome de buller(61).

En venado de campo (Ozotoceros bezoarticus) no se observaron montas entre machos a pesar de haberse registrado el comportamiento de dos grupos de machos, durante más de $200 \mathrm{~h}$ a lo largo del año (Delbene y Ungerfeld, datos no publicados). Sin embargo, el único momento en que se observó una monta entre machos fue cuando un macho se recuperaba de un tratamiento anestésico (Fumagalli, comunicación
Figura 2: Cantidad de acercamientos laterales (A), aproximación por detrás (B), olfateos (C) (- $\square-)$ y concentración de testosterona (- $\bullet$-) a lo largo de un año en carneros Corriedale y Milchschaf adultos

Figure 2. Number of lateral approaches $(A)$, behind approaches (B), sniffings (C) (- $\square-)$, and testosterone concentration (- - -) during one year in adult Corriedale and Milchschaf rams
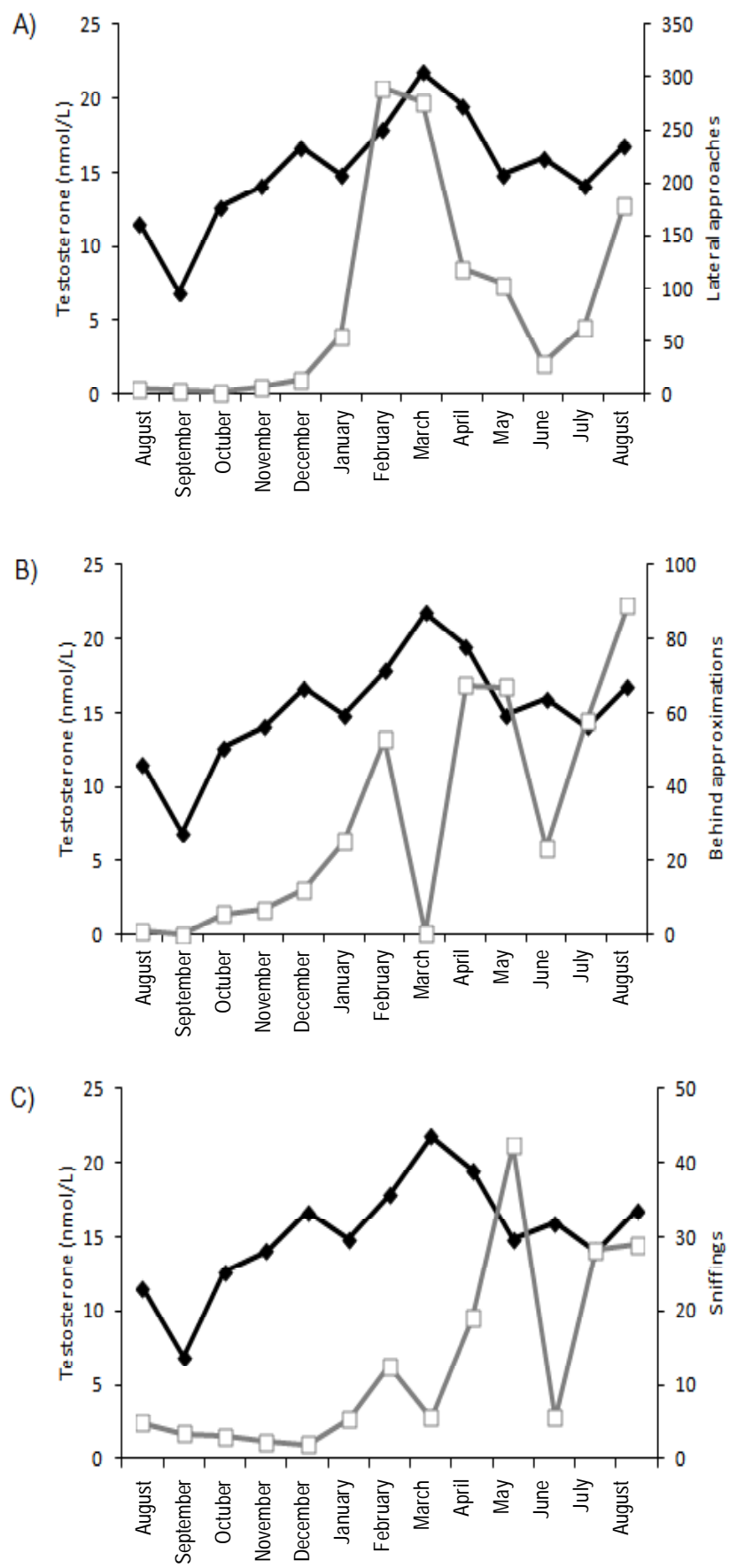
personal). La condición de este animal fue probablemente lo que permitió que se desplegara un comportamiento que normalmente no es observado en la especie. Esto coincide con el aumento de comportamientos agonistas que son dirigidos hacia los animales anestesiados, como fue reportado en carneros bighorn(62) y en el ciervo dama (Dama dama)(63).

Por tanto, considerando que los disturbios ambientales pueden provocar un aumento de montas entre machos, estos también pueden ser una herramienta útil para estudiar los factores que influyen sobre el comportamiento homosexual(56).

\section{Estacionalidad}

Muchas especies de rumiantes presentan cambios estacionales en su actividad reproductiva, lo que determina que la intensidad del comportamiento sexual varíe a lo largo del año(64). Por ello, en algunos trabajos se planteó determinar si la manifestación del comportamiento homosexual también varía a lo largo del año.

En ciervo dama la frecuencia de montas entre machos es claramente estacional, estando asociada a los tres primeros meses de crecimiento de las astas(45). En bisontes la ocurrencia del comportamiento homosexual es mayor fuera de la estación reproductiva(51). Por el contrario, en ciervo de cola blanca las montas no presentan un patrón estacional, y se observaron en frecuencia similar durante todo el año(8).

En novillos alimentados a pastoreo, se observó una mayor frecuencia del síndrome de buller en verano y otoño que en inviemo o primavera(65). En coincidencia, se reportó una mayor frecuencia del síndrome de buller en verano(61). Si bien no se estudió la causalidad, los resultados de estos autores concuerdan en que el síndrome de buller es más frecuente en los periodos del año más calientes, y que en las condiciones en que se realizaron esos trabajos frecuentemente coincide con el pastoreo en cultivares con fitoestrógenos(15). En concordancia, se ha
Testosterone serum concentration was determined weekly. The only courtship malemale behavior that showed changes relative to testosterone concentration was lateral approach, a behavior usually used by rams for wooing females $\left(P=0.006, R^{2}=0.47\right)$ (Lacuesta and Ungerfeld, unpublished) (Figure 2A). No association was found between seasonal changes in testosterone concentration and other courtship behaviors, such as approaching from behind (Figure 2B), smelling (Figure $2 \mathrm{C}$ ), mountg attempts (Figure 3B) and mounts (Figure $3 \mathrm{C}$ ).

\section{Synthesis}

This review summarized some of the factors that influence on male ruminant homosexual

Figura 3. Cantidad de montas (A) e intentos de monta (B) (- $\square$-) en carneros Corriedale y Milchschaf adultos y concentración de testosterona (- $\bullet$-) a lo largo de un año

Figure 3. Number of matings (A) and mount attempts (B) $(-\square-)$ and testosterone concentration (- $\bullet-)$ during one year in adult Corriedale and Milchschaf rams
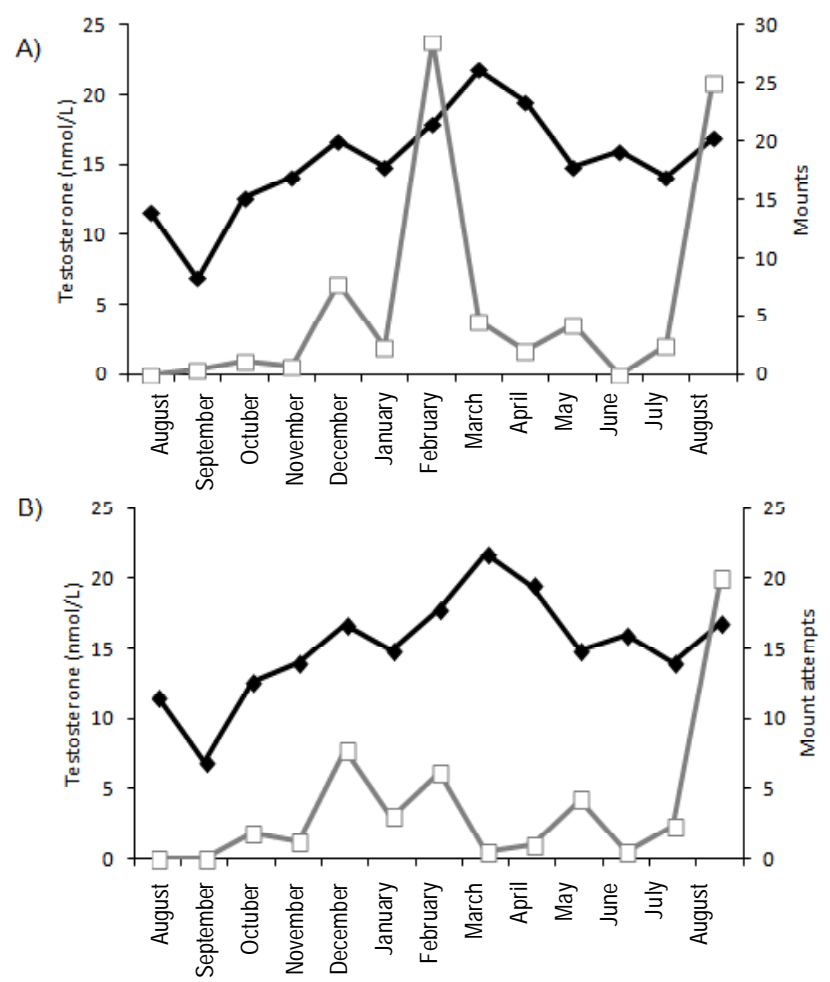
propuesto que la causa principal del síndrome buller estaría vinculada a la concentración de estrógenos, lo que promovería la liberación de feromonas sexualmente atractivas(12).

En cabras montesas (Capra pyrenaica) en cautiverio se realizaron registros semanales en dos grupos de machos con 4 y 5 machos cada uno, alojados en encierros de $250 \mathrm{~m}^{2}$. Los animales eran suplementados diariamente con cebada y alfalfa y estaban acostumbrados a la presencia humana. Registrando en forma semanal se observó un total 20 montas entre machos a lo largo de un año (Freitas-de-Melo, et al, datos no publicados). La cantidad total de montas entre machos tuvo un patrón estacional, registrándose la máxima frecuencia al inicio de la estación reproductiva, momento en que se inicia el aumento en la concentración de testosterona (Figura 1). Otros autores encontraron resultados similares en ciervo dama, especie en la que también se observó la máxima cantidad de montas entre machos en coincidencia con el aumento de la concentración de testosterona(45).

Recientemente realizamos un trabajo en que se registró en forma semanal la frecuencia de los diferentes comportamientos sexuales en un grupo de 12 carneros Corriedale $X$ Milchschaf alojados en un corral de $10 \times 10 \mathrm{~m}^{2}$ durante todo un año. A su vez, se determinó la concentración sérica de testosterona en forma semanal. El único comportamiento de cortejo cuya variación a lo largo del año se relacionó con las concentraciones de testosterona fue el de acercamiento lateral (Lacuesta y Ungerfeld, datos no publicados) (Figura 2A), comportamiento habitualmente utilizado por los carneros para cortejar a las hembras $\left(P=0.006, R^{2}=0.47\right)$. No hubo relación entre la variación estacional en la concentración de testosterona y otros comportamientos de cortejo como aproximación por detrás (Figura 2B) y olfateos (Figura 2C), o con los intentos de monta (Figura 3B) y montas (Figura 3A) entre machos. behavior, the occurrence of which seems to be multifactorial and may change in accordance with the species being studied. On one hand, it seems to be some predisposing anatomic and physiologic traits, which in some cases can partially explain the occurrence of homosexual behavior. Among these traits, the most important is the difference in the sexualy dimorphic nucleus size, which could be influenced by management practices during gestation. On the other hand, the social environment in which animals are reared seems to influence the frequency of homosexual events, although no available data demonstrate that this factor influences either heterosexual or homosexual preference. A scarcely studied aspect is genetic predisposition, as in certain ram populations there is a constant percentage of males that prefer to mount other males, and that in steers a certain percentage is frequently mounted by other steers. Several questions remain unanswered related to causes or factors which influence the occurrence of homosexuality in ruminants, as, for example, if social dominance and blood testosterone concentration are linked to homosexual behavior, being then opportunities to develop more research in the topic.

End of english version

\section{Síntesis}

Esta revisión consideró algunos de los factores determinantes del comportamiento homosexual en rumiantes machos. La ocurrencia de este comportamiento parece ser multifactorial, a la vez que puede variar de acuerdo a la especie estudiada. Por un lado parece haber factores anatomo-fisiológicos predisponentes, o que al menos en algunos casos puedan explicar parcialmente la ocurrencia del comportamiento. Entre estos, el principal es la diferencia en el tamaño y funcionalidad del núcleo sexual dimórfico, lo que podría estar influenciado por manejos durante la gestación. Por otra parte, el ambiente social en que son criados los 
animales parece influir sobre la frecuencia con que se despliegan comportamientos homosexuales, aunque no existe información que demuestre que esto influya sobre la preferencia hetero u homosexual. Un aspecto poco estudiado es la predisposición genética, ya que por ejemplo, en determinadas poblaciones de carneros hay una frecuencia estable de machos que prefieren montar a otros machos; o en poblaciones de novillos hay un porcentaje de animales que son frecuentemente montados por otros machos. Todavía existen muchas interrogantes relacionadas a las causas o factores que influyen sobre la ocurrencia de la homosexualidad en rumiantes, como por ejemplo, si la dominancia social o las concentraciones sanguíneas de testosterona están relacionadas a la conducta homosexual, siendo por lo tanto campos de estudio a profundizar.

\section{LITERATURA CITADA}

1. Poiani A. Animal homosexuality: a biosocial perspective. 1rst ed. Cambridge, Inglaterra: Cambridge University Press; 2010.

2. Roselli CE, Radhika CR, Kaufman KR. The development of male oriented behavior in rams. Front Neuroendocrinol 2011; (32): 164-169.

3. Price EO, Smith VM. The relationship of male-male mounting to mate choice and sexual performance in male dairy goats. Appl Anim Behav Sci 1984/85;(13):71-82.

4. Tennessen T, Price MA, Berg RT. The social interactions of young bulls and steers after re-grouping. Appl Anim Behav Sci 1985; (14):37-47.

5. Jago JG, Cox NR, Bass JJ, Matthews LR. The effect of prepubertal immunization against gonadotropin-releasing hormone on the development of sexual and social behavior of bulls. J Anim Sci 1997;(75):2609-2619.

6. Lott DF. The buller syndrome in American bison bulls. Appl Anim Ethol 1983;(11):183-186.

7. Bagemihl B. Biological exuberance: Animal homosexuality and natural diversity. NY: St Martin's Press; 1999.

8. Bartoš L, Holeèková J. Exciting ungulates: male-male mounting in fallow, white-tailed and red deer. In: Vasey PL, Sommer $\mathrm{V}$ editors. Homosexual behaviour in animals: An evolutionary perspective. 1rst ed. Cambridge, Inglaterra: Cambridge University Press; 2006: 154-171.

9. Ford CS, Beach FA. Patterns of sexual behavior. 1rst ed. New York, USA: Harper y Row; 1951.

10. Baker AA, Seidel GE. Why do cows mount other cows? Appl Anim Behav Sci 1985;(13):237-241.
11. Dagg Al. Homosexual behaviour and female-male mounting in mammals-a first survey. Mammal Rev 1984;(14):155185.

12. Klemm WRC, Sherry CJ, Schake LM, Sis RF. Homosexual behaviour in feedlot steers: an aggression hypothesis. Appl Anim Ethol 1983; (11):187-95.

13. Ungerfeld R, Ramos MA, Bielli A. Relationship between malemale and male-female sexual behavior in 5-6-month old male lambs. Anim Reprod Sci 2007;(100):85-390.

14. Srivastava RS, Mathur AK, Kalra DB. Effect of training ram hoggets on their adult sexual behaviour. Appl Anim Behav Sci 1989; (22):295-302.

15. Blackshaw JK, Blackshaw AW, McGlone JJ. Buller steer syndrome review. Appl Anim Behav Sci 1997;(54):97-108.

16. Edwards TA. Buller syndrome: What's behind this abnormal sexual behavior? Large Anim Vet 1995;(40):6-8.

17. Taylor LF, Booker CW, Jim GK, Guichon PT. Epidemiological investigation of the buller steer syndrome (riding behaviour) in a western canadian feedlot. Vet J 1997; (75):45-51.

18. Stookey, JM. Buller steer syndrome. University of saskatchewan western college of veterinary medicine applied ethology 2001 Available:http://www.usask.ca/wcvm/ herdmed/appliedethology/articles/bullers.html. Accesed Sep 13, 2012.

19. Vasey PL, Sommer V. Introduction. In: Sommer V, Vasey PL editors. Homosexual behaviour in animals: an evolutionary perspective. Irst ed. Cambridge, Inglaterra: Cambridge University Press; 2006:3-44.

20. Roselli CE, Stormshak F. The neurobiology of sexual partner preferences in rams. Horm Behav 2009; (55):611-620.

21. Roselli CE, Stormshak F. Prenatal programming of sexual partner preference: the ram model. Neuroendocrinol 2009; (21):359-364.

22. Hull EM, Meisel RL, Sachs BD. Male sexual behavior. In: Pfaff DW et al. editors. Hormones, brain and behavior. 1rst ed. San Diego, USA: Elsevier Science; 2002:1-138.

23. Gorski RA, Gordon JH, Shryne JE, Southam AM. Evidence for a morphological sex difference within the medial preoptic area or the rat brain. Brain Res 1978; (148):333-346.

24. Roselli CE, Larkin K, Resko JA, Stellflug JN, Stormshak F. The volume of a sexually dimorphic nucleus in the ovine medial preoptic area/anterior hypothalamus varies with sexual partner preference. Endocrinology 2004;(145):478483.

25. Roselli CE, Estill CT, Stadelman HL, Stormshak F. The volume of the ovine sexually dimorphic nucleus of the preoptic area is independent of adult testosterone concentrations. Brain Res 2009; (1249): 113-117

26. Roselli CE, Stadelman HL, Reeve R, Bishop CV, Stormshak F. The ovine sexually dimorphic nucleus of the medial preoptic area is organized prenatally by testosterone. Endocrinology 2007; (148): 4450-4457.

27. Fabre-Nys C, Venier G. Sexual differentiation of sexual behaviour and preovulatory LH surge in ewes. Psychoneuroendocrinology 1991; (16):383-396.

28. Roselli CE, Resko JA, Stormshak F. Estrogen synthesis in fetal sheep brain: effect of maternal treatment with an aromatase inhibitor. Biol Reprod 2003; (68):370-374.

29. O'Donnell L, Meachem SJ, Stanton PG, Robert I. Endocrine regulation of spermatogenesis. In: Challis JRG et al. editors. 
Physiology of reproduction. 3rd ed. San Diego, USA: Elsevier Science; 2001:1017-1070.

30. Balthazart J, Baillien M, Cornil CA, Ball GF. Preoptic aromatase modulates male sexual behavior: slow and fast mechanisms of action. Physiol Behav 2004;(83):247-270.

31. Wallen K, Baum MJ. Masculinization and defeminization in altricial and precocial mammals: comparative aspects of steroid hormone action. In: Pfaff DW et al. editors. Hormones, brain and behavior. 1rst ed. San Diego, USA: Elsevier Science; 2002:326-384.

32. Roselli CE, Schrunk J M, Stadelman HL, Resko JA, Stormshak F. The effect of aromatase inhibition on the sexual differentiation of the sheep brain. Endocrine 2006; (29):501512.

33. Roselli CE, Stormshak F. The ovine sexually dimorphic nucleus, aromatase, and sexual partner preferences in sheep. J Steroid Biochem Mol Biol 2010;(118):252-256.

34. Perkins A, Fitzgerald JA, Moss GE. A comparison of LH secretion and brain estradiol receptors in heterosexual and homosexual rams and female sheep. Horm Behav 1995; (29):31-41.

35. Blanchard DC, Cholvanich P, Blanchard RJ, Clow DW, Hammer Jr RP, Rowlett JK, Bardo MT. Serotonin, but not dopamine, metabolites are increased in selected brain regions of subordinate male rats in a colony environment. Brain Res 1991; (568):61-66.

36. Epp MP, Blasi DA, Johnson BJ, Kayser JP, Grieger DM, Stevenson JS, Minton JE. Serum steroid concentrations at different phases of production and brain monoamine oxidase type A messenger ribonucleic acid in buller steers. Prof Anim Sci 2008; (24):552-559.

37. Meikle A, Forsberg M, Garófalo EG, Carlsson MA, Lundeheim N, Rubianes E. Circulating gonadotrophins and follicular dynamics in anestrous ewes after treatment with estradiol. Anim Reprod Sci 2001; (67):79-90.

38. Ungerfeld R, Dago AL, Rubianes E, Forsberg M. Response of anestrous ewes to the ram effect after follicular wave synchronization with a single dose of estradiol-17beta. Reprod Nutr Dev 2004; (44):89-98.

39. Dorner G, Rohde W, Stahl F, Krell L, Masius WG. A neuroendocrine disposition for homosexuality in men. Arch Sexual Behav 1975; (4):1-8.

40. Gladue BA, Green R, Hellman RE. Neuroendocrine response to estrogen and sexual orientation. Science 1984; (225): 1496-1498.

41. Stormshak F, Estill CT, Resko JA, Roselli CE. Changes in LH secretion in response to an estradiol challenge in male- and female-oriented rams and in ewes. Reproduction 2008; (135): 733-738.

42. Hinch GN, Lynch JJ, Thwaites CJ. Patterns and frequency of social behaviour in young grazing bulls and steers. Appl Anim Ethol 1982;(9):15-30.

43. Roselli CE, Stormshak F, Stellflug J N, Resko JA. Relationship of serum testosterone concentrations to mate preferences in rams. Biol Reprod 2002;(67):263-268.

44. Resko JA, Perkins A, Roselli CE, Fitzgerald J A, Choate JVA, Stormshak F. Endocrine correlates of partner preference behavior in rams. Biol Reprod 1996;(55):120-126.
45. Holeckova J, Bartos L, Tomanek M. Inter-male mounting in fallow deer (Dama dama) - its seasonal pattern and social meaning. Folia Zool 2000;(49):175-81.

46. Savic I, Lindström P. PET and MRI show differences in cerebral asymmetry and functional connectivity between homo- and heterosexual subjects. Proc Nat Acad Sci. USA 2008; (27): 9403-9408.

47. Gonzalez R, Levy F, Orgeur P, Poindron P, Signoret J P. Female effect in sheep. II. Role of volatile substances from the sexually receptive female; implication of the sense of smell. Reprod Nutr Dev 1991;(31):03-109.

48. Perkins A, Fitzgerald JA. Luteinizing hormone, testosterone, and behavioral response of male-oriented rams to estrous ewes and rams. J Anim Sci 1992; (70):1787-1794.

49. Franc C, Bartos L, Hanys Z, Tomes Z. Preslaughter social activity of young bulls relating to the occurrence of darkcutting beef. Anim Prod 1988; (46):153-61.

50. Grubb P. Social organization of Soay sheep and the behaviour of ewes and lambs. In: Jewell P et al. editors. The ecology of the Soay sheep of St. Kilda. 1rst ed. London: The Athlone Press; 1974:131-159.

51. Vervaecke $H$, Roden $C$. Going with the herd: same-sex interaction and competition in American bison. In: Vasey $\mathrm{PL}$, Sommer $\mathrm{V}$ editors. Homosexual behaviour in animals: An evolutionary perspective. 1rst ed. Cambridge, Inglaterra: Cambridge University Press; 2006:131-153.

52. Ungerfeld R, González-Pensado SP. Social rank affects reproductive development in male lambs. Anim Reprod Sci 2008; (109): 161-171.

53. Katz LS, Price LS, Wallach SJR, Zenchak JJ. Sexual performance of rams reared with and without females after weaning. J Anim Sci 1988;(33):1166-1171.

54. Price EO, Borgwardt R, Blackshaw JK, Blackshaw A, Dally $M R$, Erhard $H$. Effect of early experience on the sexual performance of yearling rams. Appl Anim Behav Sci 1994; (42): 41-48.

55. Price EO, Borgwardt R, Dally MR. Effect of early fenceline exposure to estrous ewes on the sexual performance of yearling rams. Appl Anim Behav Sci 1999;(64):241-247.

56. Ungerfeld R, Lacuesta L, Damián JP, Giriboni J. (2012). Does heterosexual experience matters for bucks' homosexual mating behavior? Enviado.

57. Bartoš L, Franc C, Albiston G, Beber K. Prevention of dark cutting (DFD) beef in penned bulls at the abattoir. Meat Sci 1988; (22):213-20.

58. Mohan Raj AB, Moss BW, Rice DA, Kilpatrick DJ, McCaughey WJ, McLauchlan W. Effect of mixing male sex types of cattle on their meat quality and stress-related parameters. Meat Sci 1992;32(4):367-86.

59. Smith RF, Dobson H. Effect of preslaughter experience on behaviour, plasma cortisol and muscle $\mathrm{pH}$ in farmed red deer. Vet Rec 1990; (126): 155-8

60. Acosta JE, Schake LM, Brown GC, Vermedahl LD. Influence of implants, feed additives and pen size upon incidence of huller steers. Texas Agric Expt Sta 1981;(3758-3830):130133.

61. Brower GR, Kiracofe OH. Factors associated with the bullersteer syndrome. J Anim Sci 1978; (46):26-31.

62. Pelletier F, Hogg JT, Festa-Bianchet M. Effect of chemical immobilization on social status of bighorn rams. Anim Behav 2004; (67):1163-1165. 
Aline Freitas-de-Melo, et al. / Rev Mex Cienc Pecu 2014;5(1):91-106

63. Jennings $D J$. The effect of chemical immobilization on dominance rank in the fallow deer. Anim Behav 2007; (74): 1107-1110.

64. Prendergast BJ, Nelson RJ, Zucker I. Mammalian Seasonal Rhythms: Behavior and Neuroendocrine Substrates. In: Pfaff
DW et al. editors. Hormones, Brain and Behavior. 1rst ed. San Diego, USA: Elsevier Science; 2002:93-156.

65. Pierson RE, Jensen R, Braddy PM, Horton DP, Christie RM. Bulling among yearling feedlot steers. J Am Vet Med Assoc 1976; (169):521-523. 